\title{
The Articulation of Local Government Financial Statements and Their Effect on Its Quality
}

\author{
BELLA MEIHANA \\ ABDUL HALIM* \\ Universitas Gadjah Mada \\ EVI MARIA \\ Satya Wacana Christian University
}

\begin{abstract}
This research aims to analyze the level of articulation of the Local Government Financial Statement (LKPD) and its effects on the quality of LKPD as a basis for local government economic decision-making. Data sources used in this research are secondary data and primary data. Secondary data consisting of LKPD documents with Unqualified Opinion were obtained from the Indonesian Supreme Audit Institutions' Financial Audit Report in 2018. Secondary data analysis is carried out using content analysis techniques. The analysis is carried out by comparing the numbers of LKPD based on the set of articulation criteria built based on Government Accounting Standards and previous research. Primary data consist of semi-structured interviews with local governments, with an articulation rate of less than 100 percent. Analysis of primary data from interviews is using Miles and Huberman's model. Based on the analysis of 443 LKPD documents, it was found that 131 or 30 percent LKPD had an articulation rate of 100 percent, and 312 or 70 percent LKPD had an articulation rate of less than 100 percent. The average level of articulation of LKPD in Indonesia is 83 percent, with the lowest articulation rate of 54 percent. The interview results show that articulation affects the quality of financial statements and influences economic decisions in the budget preparation process with the function of LKPD as a comparison and prediction tool.
\end{abstract}

Keywords: Articulation, Financial statements, Local Government, Quality of Social Statements, Economic Decisions.

Abstrak - Penelitian ini bertujuan untuk menganalisis tingkat artikulasi Laporan Keuangan Pemerintah Daerah (LKPD) dan pengaruhnya terhadap kualitas LKPD sebagai dasar pengambilan keputusan ekonomi pemerintah daerah. Sumber data yang digunakan dalam penelitian ini adalah data sekunder dan data primer. Data sekunder berupa dokumen LKPD dengan pendapat Wajar Tanpa Pengecualian. Dokumendokumen tersebut diperoleh dari Laporan Hasil Pemeriksaan Keuangan Badan Pemeriksa Keuangan Indonesia tahun 2018. Analisis data sekunder dilakukan dengan menggunakan teknik analisis isi. Analisis dilakukan dengan membandingkan jumlah LKPD berdasarkan seperangkat kriteria artikulasi yang dibangun berdasarkan Standar Akuntansi Pemerintahan dan penelitian sebelumnya. Data primer berupa wawancara semi terstruktur dengan pemerintah daerah yang memiliki tingkat artikulasi kurang

*Corresponding author: abhalim58@yahoo.com 
dari $100 \%$. Analisis data primer hasil wawancara menggunakan model Miles dan Huberman. Berdasarkan analisis terhadap 443 dokumen LKPD, ditemukan bahwa 131 atau 30 persen LKPD memiliki tingkat artikulasi 100 persen dan 312 atau 70 persen LKPD memiliki tingkat artikulasi kurang dari 100 persen. Rata-rata tingkat artikulasi LKPD di Indonesia adalah 83 persen dengan tingkat artikulasi terendah 54 persen. Berdasarkan hasil wawancara menunjukkan bahwa artikulasi mempengaruhi kualitas laporan keuangan dan mempengaruhi keputusan ekonomi dalam proses penyusunan anggaran dengan fungsi LKPD sebagai alat pembanding dan prediksi.

Kata Kunci: Artikulasi, Laporan Keuangan, Pemerintah Daerah, Kualitas Laporan Sosial, Keputusan Ekonomi

\section{Introduction}

The existence of regional autonomy gives authority to the regional government to take care of government affairs and the local community's interests, including the management of regional finances. As a form of accountability and transparency to the public, regional governments are obliged to report financial accountability reports in the form of financial statements. This financial statement is provided based on the Government Accounting Standards (in Indonesia: Standard Akuntansi Pemerintahan, or SAP) regulated in Government Regulation No. 71/2010.

SAP is a guideline and standard for preparing a financial statement that can improve financial statement' quality of information (Nkundabanyanga et al., 2013; Firdaus \& Ritonga, 2018). In Indonesia, examination of the quality of local government financial statements (in Indonesia: Laporan Keuangan Pemerintah Daerah, or LKPD) and their compliance with SAP is carried out by the Indonesian Supreme Audit Institutions's (in Indonesia: Badan Pemeriksa Keuangan Republik Indonesia, or BPKRI) in the form of an audit opinion. The unqualified opinion indicates that the LKPD has been prepared following SAP (BPK RI, 2019). Besides, the unqualified opinion is the highest assessment of the financial statements' quality because it states that the financial statements have been fairly presented (Halim \& Bawono, 2011). However, Firdaus \& Ritonga's (2018) research results found that local government financial statement with an unqualified opinion does not consistently articulate 100 percent (Firdaus \& Ritonga, 2018). According to SAP, the existence of inarticulation indicates 
that the qualitative characteristics in the financial statements have not been fulfilled. Failure to fulfill any of these qualitative characteristics can affect the quality of financial statements. This condition makes research on the articulation of LKPDs, Indonesia is still an exciting issue to research.

Financial statement articulation is a relationship or linkage between financial statement components or between posts/elements in a financial statement component (Firdaus \& Ritonga, 2018). Articulation of financial statements research in the private sector was conducted by Bahnson et al. (1996) using a sample of companies in the United States from 1987 to 1990 and Kinnunen \& Koskela (1999) using a sample of companies listed on the Finnish stock exchange from 1995 to 1997. Both studies found that cash flow statements do not necessarily articulate with income statements and balance sheets. This inarticulation in cash flows is not only from operating activities but also from investing and financing activities.

In Indonesia, research on the articulation of financial statements, both in the private and public sectors, is still rare (Firdaus \& Ritonga, 2018). Christiana (2017) and Firdaus \& Ritonga (2018) have tried to research the articulation of LKPDs, Indonesia. Christiana (2017) found that of the 91 LKPDs analyzed, 11 LKPDs or 12 percent articulated 100 percent, and the remaining 80 or 88 percent articulated less than 100 percent. Firdaus \& Ritonga (2018) has conducted an analysis on the LKPDs with the unqualified opinion in 2014 in Java and Bali. This study found that of the 61 LKPDs analyzed for cash to accrual basis, only 7 LKPDs or 11.48 percent achieved a 100 percent articulation rate. Meanwhile, the remaining 54 LKPDs achieved an articulation rate of less than 100 percent. Inarticulation can result in misleading notions and material errors (Government Regulation No. 71/2010, Attachment I.01). Frischmann et al. (2010) dan Frischmann et al. (2019) also found that inarticulation can lead to habits and inaccuracies in conducting forecast analysis.

Based on the BPK-RI examination (2019), an increase in opinion in the last five years by 47 percent in 2014 to 82 percent in 2018 was found. However, this increase raises whether the unqualified opinion still shows that LKPDs in Indonesia have not been fully articulated, such as research conducted by Christiana (2017) and Firdaus \& 
Ritonga (2018) or not. Therefore, research on the articulation of LKPDs on unqualified opinions in Indonesia is interesting to do. This research will examine all financial statements in Indonesia with unqualified opinions in 2018 regarding the level of articulation and its impact on the quality of financial statements. The purpose of this research is to analyze the level of articulation of LPKD and investigate their effects on the quality of LKPD as a basis for local government economic decision-making.

There are several contributions to this research. First, contribute to the development of science in Public Sector Accounting, related to the articulation of financial statements and the quality of financial statements in local governments. Second, contribute to local government. The results of this study are expected to help local governments to know the level of articulation of their financial statements and encourage local governments to improve the quality of financial statements by increasing the level of articulation of their financial statements so that financial statements are free from misleading notions and material errors. Third, contribute to BPK-RI. The results of this study provide recommendations to the BPK-RI to be more careful in examining local government financial statements related to articulation and the format of financial statements used. Considering that local governments still use the financial statement format in cash for accrual.

\section{Theoretical Framework}

\subsection{Local Government Financial Statement Articulation}

According to Suwardjono (2013), articulation is a derivative or consequence of the concept of business units. It refers to the basic concept put forward by the Accounting Principles Board (APB) that financial statements are fundamentally related to one another (fundamentally related financial statements). According to Firdaus \& Ritonga (2018), local government financial statement (in Indonesia: Laporan Keuangan Pemerintah Daerah, or LKPD) articulation is a relationship or linkage between LKPD components or between posts/elements in the LKPD component. Articulation in local government financial statements can be observed from the Government Accounting Standards (in Indonesia: Standard Akuntansi Pemerintahan, or SAP) contained in the 
Statement of Government Accounting Standards (in Indonesia: Pernyataan Standar Akuntansi Pemerintahan, or PSAP). The articulation's presence shows the reliability in LKPD, i.e., information is presented honestly, free from material misstatement, and justified (Firdaus \& Ritonga, 2018).

The following is a description of the existence of articulation following Government Regulation No. 71/2010:

a. PSAP No. 01 concerning Financial Statements Presentation

"The equity balance on the Balance Sheet comes from the ending balance of equity on the Statement of Changes in Equity." (Paragraph 85 PSAP No. 01).

b. PSAP No. 02 concerning Cash-Based Budget Realization Report

"The remaining budget financing at the end of the reporting period is transferred to the Report on Changes to the Budget Overpayment Balance." (Paragraph 62 PSAP No. 02).

c. PSAP No. 03 concerning Cash Flow Statement

"A reporting entity shall disclose the cash and cash equivalents components in the Cash Flow Statements that have the same amount as the related items on the Balance Sheet.” (Paragraph 59 PSAP No. 03).

d. PSAP No. 12 concerning Operational Statement

"The Operational Statement is prepared to complement the reporting of the accrual accounting cycle (full accrual accounting cycle) so that the preparation of the Operational Statement, Change in Equity Statement, and Balance Sheet have an accountable linkage." (Paragraph 7 PSAP No.12).

"The balance of the LO-Surplus/Deficit at the end of the reporting period is transferred to the Statement of Changes in Equity." (Paragraph 52 PSAP No.12).

\subsection{Local Government Financial Statement Qualitative Characteristics}

The qualitative characteristics of LKPD are described in Government Regulation No. 71/2010 concerning SAP as outlined in the PSAP. The qualitative characteristics of financial statements are normative measures embodied in accounting information to meet its objectives (Salim et al., 2019). As a normative requirement for a financial 
statement to meet the desired quality standards, financial statements must meet the qualitative characteristics of LKPD, which consist:

a. Relevant occur when the information in these financial statements can affect its users' decisions. Financial statement users can use existing financial information to evaluate the past, present, and predict the future. The relevant information has feedback benefits and predictive benefits and is timely.

b. Reliable occurs when the information in the financial statements is presented honestly, free from misleading understanding and material misstatement, and can be verified.

c. Comparable can be made internally and externally by an entity. Internally, financial statements are compared with the previous year's financial statements as long as they have the same accounting policies. Externally, an entity can compare its financial statements with other entities to determine the entity's weaknesses or strengths and affect decision making.

d. Understandable, assuming that the user has knowledge of financial statements and is willing to learn the information.

\subsection{Local Government Financial Statement Components}

Financial statements are the primary means used by a company in communicating financial information to outside parties (Kieso et al., 2018). In the context of government, financial statements are a form of accountability. Financial statements in Indonesia are provided as a concrete effort to realize transparency and accountability in managing state finances that are prepared based on generally accepted government accounting standards (Law No. 17/2003). LKPDs are prepared by applying an accrualbased SAP under the mandate of Law No. 23/2014 and Government Regulation No. 71/2010. Accrual-based means the accounting principles applied on an accrual basis in preparing and presenting LKPDs. In accrual-based SAP, income, expenses, assets, debt, and equity in LKPD are recognized on an accrual basis.

Meanwhile, revenue, expenditure, and financing in budget implementation reporting are recognized on the basis set out in the state budget (in Indonesia: Anggaran 
Pendapatan dan Belanja Negara, or APBN) or regional revenue and expenditure budget (in Indonesia: Anggaran Pendapatan dan Belanja Daerah, or APBD). LKPD, on an accrual basis, has a component of LKPD, and each component of LKPD consists of LKPD posts. The LKPD component consists of budgetary reports and financial statements. Ritonga (2017) classifies LKPD into three categories, as in Table 2.1.

Table 2.1

Accrual-Based LKPD Components

\begin{tabular}{ll}
\hline \multicolumn{1}{c}{ Category } & \multicolumn{1}{c}{ Type of Financial Statements } \\
\hline \multirow{4}{*}{ Budgetary Reports } & Budget Realization Statement (in Indonesia: Laporan Realisasi \\
& Anggaran, or LRA) \\
& Statement on Changes in the Excess Budget Balance (in \\
& Indonesia: Laporan Perubahan Saldo Anggaran Lebih, or \\
& LPSAL) \\
& - Balance Sheet \\
& - Operational Statement (in Indonesia: Laporan Operasional, or \\
& LO) \\
Financial Statements & - Cash Flow Statement (in Indonesia: Laporan Arus Kas, or LAK) \\
& - Statement of Changes in Equity (in Indonesia: Laporan \\
& Perubahan Ekuitas, or LPE) \\
\hline Notes to Financial & $\begin{array}{l}\text { Notes to Financial Statements (in Indonesia: Catatan atas Laporan } \\
\text { Keuangan, or CaLK) }\end{array}$ \\
\hline Statements &
\end{tabular}
Source: Ritonga (2017)

\subsection{The Relevance of Articulation to the Quality of Financial Statements and Economic}

Decision Making

Financial statements are helpful when the information compiled is high quality and relevant to its users to make economic decisions. According to Jones \& Irvine (2004), economic decisions make business decisions that involve money using accounting information from financial statements. Information is useful in facilitating when making decisions so that quality financial information is needed. Good quality financial information will result in the right decisions. Financial information must meet satisfactory standards (Nurfaidah, 2013). Accounting standards play an essential role in improving managerial incentives using financial statements (Chen et al., 2010). Nkundabanyanga et al. (2013) also found that accounting standards and legal frameworks were positively related to Uganda's quality of financial statements. 
The financial statement quality standards in question must meet the characteristics of financial statements as stated by Widarsono (2007) and Nurfaidah (2013), including relevance, reliability, complete and concise, understandable, verifiable, consistency, and comparable. Furthermore, in terms of output from financial statements, it also assesses financial statements' quality (Widarsono, 2007; Nurfaidah, 2013). Wolk et al. (2013) explain that output-oriented principles express financial statements' quality. It studies the considerations from the point of view of users and compilers of financial statements. The concept of comparability is the focus of users of financial statements. Meanwhile, consistency and uniformity are the focus of financial statement compilers.

Indonesia has an SAP regulated in Government Regulation No. 71/2010 in improving the quality and comparability of the preparation of government financial statements. This SAP is prepared by the Government Accounting Standards Committee (in Indonesia: Komite Standar Akuntansi Pemerintahan, or KSAP) as a setting body standard after receiving a balance from the BPK as referred to in Law No. 17/2003. In SAP, LKPD must meet the qualitative characteristics of financial statements, namely relevant, reliable, comparable, and understood. Therefore, the information in LKPD can be of quality if it is prepared following SAP, meets the qualitative characteristics of financial statements, and is helpful for its users. The existence of qualified information will help users make informed decisions.

\section{Research Method}

\subsection{Study Objects and Samples}

The object of this articulation study was the local government who received the unqualified opinion in 2018. The selection of research objects was carried out using a purposive sampling technique. This approach was carried out by determining the author's considerations to obtain a sample according to the objectives (Sugiyono, 2015). These considerations are:

a. LKPD that the BPK-RI has audited with the consideration of a guarantee to the audited LKPD that the report has been prepared moderately and following applicable accounting standards (Mahmudi, 2016). 
b. LKPD in 2018, this criterion was set because the LKPD in 2018 was the most recent LKPD that had been audited and issued by BPK-RI at the time of this research.

c. LKPD with an unqualified opinion. It considers unqualified opinion as to the highest opinion on the quality of LKPD, indicating that LKPD has been prepared in a transparent and accountable manner (Halim \& Bawono, 2011).

d. Using semi-structured interviews, local governments with an articulation rate of less than $100 \%$ will be designated as primary data collection participants. It is used to answer how inarticulation affects the quality of LKPD and its effect on local governments' economic decision-making.

e. The Financial and Asset Management Agency (in Indonesia: Badan Pengelola Keuangan dan Aset, or BPKA) will be appointed as the interviewee due to their duties and functions related to this research.

The secondary data source was BPK RI financial audit report (in Indonesia: Laporan Hasil Pemeriksaan, or LHP) in 2019 for LKPD in 2018. Secondary data were used to explore in-depth the articulation rate of LKPD in 2018. Meanwhile, primary data were obtained from semi-structured interviews with local governments with less than 100 percent articulation rates. Primary data were used in a deeper analysis of the effect of articulation on the quality of financial statements as a basis for economic decision-making.

\subsection{Study Approach}

A case study qualitative research approach was used in this study. A qualitative study approach is used in researching natural objects, the researcher is the key instrument, and the sampling is done purposively and snowball (Sugiyono, 2015). A qualitative approach is also applied to explore and understand individuals' or groups' meaning related to social and community problems (Creswell, 2014). The exploration carried out by this study was related to the articulation of LKPD in 2018, which obtained an unqualified opinion from BPK-RI. 
The researcher used the case study approach in evaluating a case, program, event, activity, process, or individual in-depth (Creswell, 2014). Case studies focus on gathering information about specific objects, events, or activities, such as a specific business unit or organization (Sekaran \& Bougie, 2016). This case study was intended to get a clear picture of a problem that must be resolved in a real way by observing various viewpoints and perspectives and using various data collection methods. The case study approach in this study aimed to determine the level of articulation of LKPD in 2018 and how it affects the quality of LKPD, which is used as a consideration in making economic decisions.

\subsection{Analysis Technique}

Analysis of document data in this study used the content analysis technique. Content analysis is one of the techniques used in analyzing document data (Moleong, 2015). Content analysis is defined as a technique by finding the characteristics of messages objectively and systematically and then concluding. Krippendorff (1981) developed the content analysis scheme consisting of content analysis steps: first, unitizing. This stage is carried out by acquiring the LHP document for the 2018 LKPD from the BPK-RI. The financial statement components analyzed consisted of the Budget Realization Statement (LRA), the Statement on Changes in the Excess Budget Balance (LPSAL), the Operational Statement (LO), the Change in Equity Statement (LPE), the Balance Sheet, the Cash Flow Statement (LAK), and Notes to Financial Statements (CaLK) if needed in adding information.

Second, sampling. The sample in this study is the LKPD document in 2018 with an unqualified opinion in 2018. There were 443 local governments in this sample. Third, recording. This stage was performed by determining the LKPD articulation criteria according to the accrual-based SAP. This criterion was based on the PSAP previously described in CHAPTER II. This criterion was also supported by the articulation criteria developed (Firdaus \& Ritonga, 2018). There are thirteen criteria determined in determining the level of articulation of LKPD. These criteria can be seen in Table 3.1. 
Based on these criteria, the figures for each component of the LKPD obtained were then be entered into a computer application using Ms. Excel.

Table 3.1.

LKPD Articulation Criteria

\begin{tabular}{|c|c|c|c|c|}
\hline Articulation & $\begin{array}{c}\text { Criteria } \\
\text { Code }\end{array}$ & \multicolumn{3}{|c|}{ Articulation Criteria } \\
\hline \multirow{2}{*}{$\begin{array}{l}\text { LRA \& } \\
\text { LPSAL }\end{array}$} & A. 1 & SiLPA Value in LRA & $=$ & $\begin{array}{l}\text { Current Year SiLPA Value in } \\
\text { LPSAL }\end{array}$ \\
\hline & A. 2 & $\begin{array}{l}\text { Previous end-year SiLPA in } \\
\text { LRA }\end{array}$ & $=$ & Initial SiLPA in LPSAL \\
\hline \multirow{6}{*}{$\begin{array}{l}\text { LRA \& } \\
\text { LAK }\end{array}$} & B. 1 & Income in LRA & $=$ & \begin{tabular}{|c} 
Cash Inflows from Operating \\
Activities + Cash Inflows from \\
Investing Activities - Proceeds from \\
Sales of Segregated Regional Assets \\
- Disbursement of Reserve Funds \\
\end{tabular} \\
\hline & B. 2 & $\begin{array}{c}\text { Funding Receipts - Use of } \\
\text { SILPA - Disbursement of } \\
\text { Reserve Funds - Proceeds from } \\
\text { Sales of Separated Regional } \\
\text { Assets }\end{array}$ & $=$ & $\begin{array}{c}\text { Cash Inflows from Funding } \\
\text { Activities }\end{array}$ \\
\hline & B. 3 & Expenditure and Transfer & $=$ & \begin{tabular}{|c|} 
Cash Outflows from Operating \\
Activities + Cash Outflows from \\
Investing Activities - Formation of \\
Reserve Funds - Government Equity \\
Participation \\
\end{tabular} \\
\hline & B.4 & $\begin{array}{c}\text { Financing Expenditures - } \\
\text { Establishment of Reserve } \\
\text { Funds - Government Equity } \\
\text { Participation - Regional Loans }\end{array}$ & $=$ & $\begin{array}{c}\text { Cash Outflows from Funding } \\
\text { Activities }\end{array}$ \\
\hline & B.5 & $\begin{array}{l}\text { Income in LRA + Funding } \\
\text { Receipts - Use of SILPA }\end{array}$ & $=$ & $\begin{array}{c}\text { Cash Inflows from Operating } \\
\text { Activities + Cash Inflows from } \\
\text { Investing Activities + Cash Inflows } \\
\text { from Funding Activities }\end{array}$ \\
\hline & B.6 & $\begin{array}{l}\text { Expenditure }+ \text { Transfer }+ \\
\text { Financing Expenses }\end{array}$ & $=$ & $\begin{array}{c}\text { Cash Outflows from Operating } \\
\text { Activities + Outflows from Investing } \\
\text { Activities + Cash Outflows from } \\
\text { Financing Activities } \\
\end{array}$ \\
\hline LO \& LPE & C. 1 & LO Surplus/Deficit & $=$ & LO Surplus/Deficit in LPE \\
\hline \multirow{2}{*}{$\begin{array}{l}\text { Balance } \\
\text { Sheet \& } \\
\text { LPE }\end{array}$} & D. 1 & $\begin{array}{l}\text { Final equity on the balance } \\
\text { sheet for the previous period }\end{array}$ & $=$ & Initial equity in LPE \\
\hline & D.2 & Equity in the balance sheet & $=$ & Final equity in LPE \\
\hline $\begin{array}{c}\text { Balance } \\
\text { Sheet \& } \\
\text { LAK } \\
\end{array}$ & E.1 & Cash value in the balance sheet & $=$ & Final cash value in LAK \\
\hline
\end{tabular}




\begin{tabular}{|c|c|c|c|c|}
\hline Articulation & $\begin{array}{c}\text { Criteria } \\
\text { Code }\end{array}$ & Articulation Criteria \\
\hline $\begin{array}{c}\text { LAK \& } \\
\text { LPSAL }\end{array}$ & F.1 & The final cash balance in LAK & $\geq$ & Final SAL in LPSAL \\
\hline
\end{tabular}

Fourth, reduction or simplification was conducted using the percentage descriptive technique developed. The percentage descriptive technique is used to calculate conformity by making a percentage of the available data, which will then be described by Ritonga (2010). The calculation of the percentage descriptive technique can be formulated as follows:

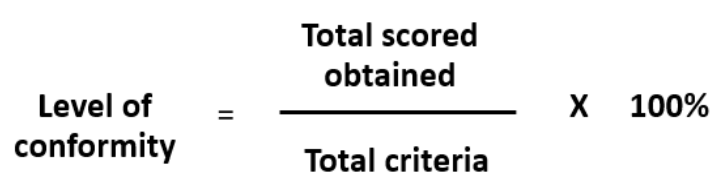

With this formula, the scores in the LKPD that match the specified criteria will get a score of 1 . If unsuitable, a score of 0 . The scores in each of the LKPD will then be added up to obtain the total value/score. The total value/score obtained was divided by the total criteria and multiplied by $100 \%$ to get the percentage level of conformity or level of articulation of the LKPD.

Fifth, inferring. Conclusion drawing is obtained from the analysis results in the previous stages, simplified in a tabular form to facilitate readers to understand the information of this study. Sixth, narrating. Each result presented in tabular form was then narrated. It was performed to make it easier for readers to understand the meaning of each table presented.

Data analysis from semi-structured interviews was carried out using Miles \& Huberman's (2014) model. Previously, the researcher prepared interview guidelines in collecting data through semi-structured interviews. During the interview, the researcher analyzed the participants' answers. It was conducted if there was an unsatisfactory answer so that the researcher could immediately continue the question again until the data obtained is credible. There is three flow of activities in this analysis process that coincide. First, data reduction is carried out in sharpening, classifying, directing, removing unnecessary, and organizing data to draw verified conclusions. The vital 
information to be obtained in the interview is the influence of LKPD articulation on LKPD information quality, which is used as the basis for making local government economic decisions. Second, data presentation. After finishing data reduction, the next step was presenting the data forming codes and patterns from the results of data reduction, which will then be narrated. The narrative provided an overview of LKPD articulation's influence on LKPD information, which is used to make economic decisions in the government. Third, conclusion drawing/verification. The final stage of the study data analysis was drawing conclusions or verification. Drawing conclusions/verification was conducted by identifying the effect of LKPD articulation on LKPD information used as a basis for making economic decisions in the government.

\subsection{Validity and Reliability Tests}

In fulfilling the study objectives to analyze the 2018 LKPD articulation rate, the document data validity test was carried out through data triangulation, i.e., informing the results of the LKPD articulation rate to the relevant local government when they want to conduct interviews. Meanwhile, the supervisory lecturer audit carried out the reliability test by examining and documenting the entire study process. For study objectives regarding the analysis of the effect of articulation on LKPD information quality, which is used as the basis for economic decision-making, the validity test was carried out through data triangulation and member checks on interview participants and descriptions of interview results. Meanwhile, the reliability test was carried out by documenting all procedures and steps from the initial preparation to analyzing the interview results.

\section{Results and Discussion}

\subsection{Local Government Financial Statement Articulation Analysis Results}

Document data analysis was carried out in fulfilling the study objectives, i.e., to determine the level of articulation of LKPD in 2018. The LKPD documents analyzed were LKPD documents that received an unqualified opinion. Based on these criteria, 443 LKPD audited by BPK-RI were obtained in 2018. From 443 LKPD with unqualified 
opinion came from 32 out of 34 provincial governments (94 percent), 327 from 415 district governments ( 79 percent), and 84 from 93 city governments (90 percent). LKPD analysis was carried out by comparing the numbers in the financial statement components according to the specified criteria based on the PSAP and the criteria established by Firdaus \& Ritonga (2018). The analysis of 443 LKPD document data in 2018 shows that 131 local governments, or around 30 percent, show a 100 percent level of articulation. The rest, 312 local governments, has an articulation rate of less than 100 percent. The number of local governments with an articulation rate of 100 percent or less than 100 percent is presented in Table 4.1. The average local government in Indonesia in 2018 had an articulation rate of 83 percent. The lowest average articulation rate for each province was DKI Jakarta, with an articulation rate of 54 percent. The average articulation rate for each province can be seen in Table 4.1.

Table 4.2 shows the level of fulfillment of the 2018 LKPD articulation criteria. These criteria consist of thirteen assessment criteria. These criteria were grouped into six groups of articulations between LKPD components, i.e., LRA and LPSAL, LRA and LAK, LO and LPE, LPE and Balance, Balance and LAK, and LAK \& LPSAL. Based on the analysis results, the articulation criteria between the LRA and LAK components had the lowest articulation fulfillment, namely an average of 74 percent. Among the LRA and LAK criteria, the lowest fulfillment of codes B. 3 and B.4 with 74 percent or only 326 and 328 LKPD fulfilled the articulation criteria. Articulation between LAK and LPSAL components was the second-lowest for fulfilling the criteria for articulation rate, which was 77 percent or only 341 LPKDs met the criteria. In comparison, the highest fulfillment was in articulating LO and LPE components with a 99 percent compliance rate or a total of 438 LKPDs that meet the criteria. However, it decreased compared to the LKPD articulation throughout Java and Bali in 2015 by Christiana (2017), with an articulation fulfillment level between LO and LPE components of 100 percent. 
Table 4.1

LKPD Articulation Rate Throughout Indonesia Per Province of 2018

\begin{tabular}{|c|c|c|c|c|}
\hline \multirow{2}{*}{ No. } & \multirow{2}{*}{$\begin{array}{c}\text { Local Government } \\
\text { (Provincial Area) }\end{array}$} & \multicolumn{2}{|c|}{ Articulation Rate } & \multirow[t]{2}{*}{ LKPD Counts } \\
\hline & & $100 \%$ & $<100 \%$ & \\
\hline 1 & Aceh Province & 12 & 12 & 24 \\
\hline 2 & North Sumatera Province & 5 & 12 & 17 \\
\hline 3 & West Sumatera Province & 5 & 14 & 19 \\
\hline 4 & Riau Province & 5 & 8 & 13 \\
\hline 5 & Jambi Province & 2 & 10 & 12 \\
\hline 6 & South Sumatera Province & 4 & 14 & 18 \\
\hline 7 & Bengkulu Province & 2 & 5 & 7 \\
\hline 8 & Lampung Province & 10 & 4 & 14 \\
\hline 9 & Bangka Belitung Island Province & 0 & 4 & 4 \\
\hline 10 & Riau Island Province & 0 & 8 & 8 \\
\hline 11 & DKI Jakarta Province & 0 & 1 & 1 \\
\hline 12 & West Java Province & 3 & 22 & 25 \\
\hline 13 & Central Java Province & 5 & 30 & 35 \\
\hline 14 & D.I Yogyakarta Province & 2 & 4 & 6 \\
\hline 15 & East Java Province & 15 & 21 & 36 \\
\hline 16 & Banten Province & 4 & 5 & 9 \\
\hline 17 & Bali Province & 4 & 6 & 10 \\
\hline 18 & West Nusa Tenggara Province & 0 & 11 & 11 \\
\hline 19 & East Nusa Tenggara Province & 0 & 8 & 8 \\
\hline 20 & West Kalimantan Province & 2 & 9 & 11 \\
\hline 21 & Central Kalimantan Province & 3 & 11 & 14 \\
\hline 22 & South Kalimantan Province & 7 & 7 & 14 \\
\hline 23 & East Kalimantan Province & 2 & 8 & 10 \\
\hline 24 & North Kalimantan Province & 0 & 4 & 4 \\
\hline 25 & North Sulawesi Province & 3 & 12 & 15 \\
\hline 26 & Central Sulawesi Province & 3 & 7 & 10 \\
\hline 27 & North Sulawesi Province & 9 & 12 & 21 \\
\hline 28 & Southeast Sulawesi Province & 8 & 9 & 17 \\
\hline 29 & Gorontalo Province & 2 & 5 & 7 \\
\hline 30 & West Sulawesi Province & 3 & 4 & 7 \\
\hline 31 & Maluku Province & 5 & 1 & 6 \\
\hline 32 & North Maluku Province & 2 & 7 & 9 \\
\hline 33 & Papua Province & 4 & 7 & 11 \\
\hline 34 & West Papua Province & 0 & 10 & 10 \\
\hline & $\begin{array}{r}\text { Total } \\
\end{array}$ & 131 & 312 & 443 \\
\hline & National Percentage & $30 \%$ & $70 \%$ & $100 \%$ \\
\hline
\end{tabular}




\begin{tabular}{|c|c|c|c|c|c|c|c|c|c|c|c|c|c|c|c|c|}
\hline \multirow[t]{2}{*}{ No. } & \multirow[t]{2}{*}{$\begin{array}{c}\text { Local Government } \\
\text { (Provincial Area) }\end{array}$} & \multicolumn{2}{|c|}{$\begin{array}{l}\text { LRA \& } \\
\text { LPSAL }\end{array}$} & \multicolumn{6}{|c|}{ LRA \& LAK } & \multirow{2}{*}{$\begin{array}{c}\text { LO } \\
\& \\
\text { LPE } \\
\text { C. } 1\end{array}$} & \multicolumn{2}{|c|}{$\begin{array}{c}\text { LPE \& } \\
\text { Balance } \\
\text { Sheet }\end{array}$} & \multirow{2}{*}{$\begin{array}{c}\begin{array}{c}\text { Balance } \\
\text { Sheet }\end{array} \\
\text { \& LAK } \\
\text { E.1 }\end{array}$} & \multirow{2}{*}{$\begin{array}{c}\text { LAK \& } \\
\text { LPSAL } \\
\text { F.1 }\end{array}$} & \multirow[t]{2}{*}{$\begin{array}{l}\text { Total } \\
\text { Score }\end{array}$} & \multirow[t]{2}{*}{$\%$} \\
\hline & & A.1 & A.2 & B.1 & B.2 & B.3 & B.4 & B.5 & B.6 & & D.1 & D.2 & & & & \\
\hline 1 & Aceh Province & 23 & 24 & 18 & 24 & 21 & 22 & 18 & 21 & 24 & 24 & 24 & 18 & 23 & 284 & $91 \%$ \\
\hline 2 & North Sumatera Province & 17 & 17 & 13 & 16 & 10 & 13 & 14 & 13 & 17 & 17 & 16 & 10 & 17 & 190 & $86 \%$ \\
\hline 3 & West Sumatera Province & 18 & 19 & 13 & 17 & 9 & 14 & 13 & 8 & 19 & 19 & 19 & 17 & 17 & 202 & $82 \%$ \\
\hline 4 & Riau Province & 13 & 13 & 10 & 12 & 9 & 13 & 10 & 9 & 13 & 13 & 13 & 9 & 12 & 149 & $88 \%$ \\
\hline 5 & Jambi Province & 12 & 12 & 3 & 12 & 5 & 9 & 3 & 5 & 12 & 12 & 12 & 10 & 11 & 118 & $76 \%$ \\
\hline 6 & South Sumatera Province & 17 & 17 & 14 & 16 & 16 & 11 & 14 & 16 & 17 & 17 & 17 & 14 & 17 & 203 & $87 \%$ \\
\hline 7 & Bengkulu Province & 7 & 7 & 6 & 6 & 6 & 5 & 6 & 6 & 7 & 7 & 7 & 6 & 6 & 82 & $90 \%$ \\
\hline 8 & Lampung Province & 14 & 14 & 12 & 14 & 13 & 13 & 12 & 13 & 14 & 14 & 14 & 13 & 13 & 173 & $95 \%$ \\
\hline 9 & Bangka Belitung Island Province & 4 & 3 & 2 & 3 & 1 & 3 & 2 & 1 & 4 & 4 & 4 & 2 & 4 & 37 & $71 \%$ \\
\hline 10 & Riau Island Province & 8 & 7 & 1 & 6 & 3 & 5 & 1 & 3 & 8 & 8 & 8 & 6 & 8 & 72 & $69 \%$ \\
\hline 11 & DKI Jakarta Province & 0 & 1 & 0 & 0 & 0 & 1 & 0 & 0 & 1 & 1 & 1 & 1 & 1 & 7 & $54 \%$ \\
\hline 12 & West Java Province & 24 & 21 & 19 & 20 & 19 & 17 & 18 & 19 & 23 & 24 & 24 & 14 & 24 & 266 & $82 \%$ \\
\hline 13 & Central Java Province & 35 & 35 & 21 & 32 & 29 & 15 & 22 & 29 & 35 & 32 & 32 & 27 & 32 & 376 & $83 \%$ \\
\hline 14 & D.I Yogyakarta Province & 5 & 6 & 4 & 4 & 5 & 5 & 5 & 6 & 6 & 6 & 6 & 5 & 6 & 13 & $88 \%$ \\
\hline 15 & East Java Province & 35 & 35 & 28 & 29 & 35 & 27 & 30 & 34 & 36 & 36 & 36 & 26 & 33 & 420 & $90 \%$ \\
\hline 16 & Banten Province & 8 & 9 & 7 & 7 & 8 & 7 & 7 & 7 & 9 & 9 & 9 & 9 & 8 & 104 & $89 \%$ \\
\hline 17 & Bali Province & 9 & 10 & 7 & 6 & 8 & 7 & 7 & 9 & 10 & 10 & 10 & 8 & 10 & 111 & $85 \%$ \\
\hline 18 & West Nusa Tenggara Province & 11 & 10 & 2 & 7 & 2 & 8 & 2 & 2 & 11 & 11 & 11 & 7 & 10 & 94 & $66 \%$ \\
\hline 19 & East Nusa Tenggara Province & 7 & 7 & 4 & 5 & 3 & 7 & 4 & 3 & 8 & 8 & 8 & 6 & 7 & 77 & $74 \%$ \\
\hline 20 & West Kalimantan Province & 10 & 7 & 7 & 11 & 7 & 8 & 7 & 7 & 11 & 11 & 11 & 10 & 11 & 118 & $83 \%$ \\
\hline 21 & Central Kalimantan Province & 14 & 14 & 13 & 12 & 14 & 10 & 14 & 14 & 14 & 14 & 14 & 7 & 10 & 164 & $90 \%$ \\
\hline 22 & South Kalimantan Province & 14 & 14 & 9 & 11 & 13 & 13 & 10 & 13 & 14 & 14 & 14 & 10 & 14 & 163 & $90 \%$ \\
\hline
\end{tabular}




\begin{tabular}{|c|c|c|c|c|c|c|c|c|c|c|c|c|c|c|c|c|c|}
\hline \multirow[t]{2}{*}{ No. } & \multirow{2}{*}{\multicolumn{2}{|c|}{$\begin{array}{l}\text { Local Government } \\
\text { (Provincial Area) }\end{array}$}} & \multicolumn{2}{|c|}{$\begin{array}{l}\text { LRA \& } \\
\text { LPSAL }\end{array}$} & \multirow[b]{2}{*}{ B.1 } & \multicolumn{4}{|c|}{ LRA \& LAK } & \multirow{2}{*}{\multicolumn{2}{|c|}{$\begin{array}{cc} & \text { LO } \\
& \text { \& } \\
& \text { LPE } \\
& \\
\text { B.6 } & \text { C.1 } 1\end{array}$}} & \multicolumn{2}{|c|}{$\begin{array}{c}\text { LPE \& } \\
\text { Balance } \\
\text { Sheet }\end{array}$} & \multirow{2}{*}{$\begin{array}{c}\text { Balance } \\
\text { Sheet } \\
\text { \& LAK } \\
\text { E.1 }\end{array}$} & \multirow{2}{*}{$\begin{array}{c}\text { LAK \& } \\
\text { LPSAL } \\
\text { F.1 }\end{array}$} & \multirow[t]{2}{*}{$\begin{array}{l}\text { Total } \\
\text { Score }\end{array}$} & \multirow[t]{2}{*}{$\%$} \\
\hline & & & A.1 & A.2 & & B.2 & B.3 & B.4 & B.5 & & & D.1 & D.2 & & & & \\
\hline 23 & East Kalimantan Province & & 10 & 10 & 7 & 9 & 8 & 6 & 8 & 8 & 10 & 10 & 10 & 9 & 9 & 114 & $88 \%$ \\
\hline 24 & North Kalimantan Province & & 4 & 4 & 1 & 3 & 1 & 1 & 1 & 1 & 4 & 4 & 4 & 4 & 4 & 36 & $69 \%$ \\
\hline 25 & North Sulawesi Province & & 15 & 15 & 8 & 12 & 7 & 14 & 10 & 9 & 15 & 15 & 15 & 12 & 11 & 158 & $81 \%$ \\
\hline 26 & Central Sulawesi Province & & 10 & 10 & 5 & 9 & 5 & 9 & 5 & 5 & 10 & 10 & 10 & 9 & 10 & 107 & $82 \%$ \\
\hline 27 & North Sulawesi Province & & 20 & 21 & 19 & 21 & 20 & 13 & 19 & 21 & 21 & 21 & 21 & 17 & 20 & 254 & $93 \%$ \\
\hline 28 & Southeast Sulawesi Province & & 17 & 17 & 15 & 16 & 16 & 12 & 14 & 16 & 17 & 17 & 17 & 15 & 16 & 205 & $93 \%$ \\
\hline 29 & Gorontalo Province & & 7 & 7 & 5 & 7 & 5 & 5 & 5 & 5 & 7 & 7 & 7 & 5 & 7 & 79 & $87 \%$ \\
\hline 30 & West Sulawesi Province & & 7 & 7 & 5 & 6 & 6 & 6 & 6 & 6 & 6 & 6 & 6 & 6 & 6 & 79 & $87 \%$ \\
\hline 31 & Maluku Province & & 5 & 5 & 6 & 6 & 6 & 4 & 6 & 6 & 6 & 6 & 6 & 5 & 5 & 72 & $92 \%$ \\
\hline 32 & North Maluku Province & & 7 & 7 & 5 & 9 & 5 & 8 & 5 & 5 & 8 & 9 & 8 & 6 & 6 & 88 & $75 \%$ \\
\hline 33 & Papua Province & & 10 & 10 & 7 & 10 & 9 & 9 & 7 & 9 & 11 & 11 & 11 & 8 & 11 & 123 & $86 \%$ \\
\hline \multirow[t]{3}{*}{34} & West Papua Province & & 10 & 10 & 1 & 10 & 2 & 8 & 1 & 2 & 10 & 10 & 10 & 10 & 8 & 92 & $71 \%$ \\
\hline & & Total & 427 & 425 & 297 & 388 & 326 & 328 & 306 & 331 & 438 & 437 & 435 & 341 & 407 & 4830 & \\
\hline & National Perce & entage & $96 \%$ & $96 \%$ & $67 \%$ & $88 \%$ & $74 \%$ & $74 \%$ & $69 \%$ & $75 \%$ & $99 \%$ & $99 \%$ & $98 \%$ & $77 \%$ & $92 \%$ & & $83 \%$ \\
\hline
\end{tabular}

Source: Processed data 
The Indonesian Journal of Accounting Research - Sept, Vol. 24 , No.3 , 2021

Table 4.3

LKPD Articulation Rate of Yogyakarta Special Region Provincial Area

\begin{tabular}{|c|c|c|c|c|c|c|c|c|c|c|c|c|c|c|c|c|}
\hline \multirow[t]{2}{*}{ No } & \multirow[t]{2}{*}{ Local Government } & \multicolumn{2}{|c|}{$\begin{array}{l}\text { LRA \& } \\
\text { LPSAL }\end{array}$} & \multicolumn{6}{|c|}{ LRA \& LAK } & \multirow{2}{*}{$\begin{array}{c}\text { LO } \\
\& \\
\text { LPE } \\
\text { C.1 }\end{array}$} & \multicolumn{2}{|c|}{$\begin{array}{c}\text { LPE \& } \\
\text { Balance } \\
\text { Sheet }\end{array}$} & \multicolumn{2}{|c|}{$\begin{array}{cc}\text { Balance } & \text { LAK } \\
\text { Sheet \& } \\
\text { \& LAK LPSAL } \\
\end{array}$} & \multirow[t]{2}{*}{$\begin{array}{l}\text { Total } \\
\text { Score }\end{array}$} & \multirow[t]{2}{*}{$(\%)$} \\
\hline & & A.1 & A.2 & B.1 & B.2 & B.3 & B.4 & B.5 & B.6 & & D.1 & D.2 & E.1 & F.1 & & \\
\hline 1 & $\begin{array}{ll}\text { Yogyakarta } & \text { Special } \\
\text { Region Province } & \end{array}$ & 1 & 1 & 0 & 0 & 0 & 0 & 1 & 1 & 1 & 1 & 1 & 1 & 1 & 9 & $69 \%$ \\
\hline 2 & Bantul Regency & 1 & 1 & 1 & 1 & 1 & 1 & 1 & 1 & 1 & 1 & 1 & 1 & 1 & 13 & $100 \%$ \\
\hline 3 & Gunungkidul Regency & 1 & 1 & 0 & 1 & 1 & 1 & 0 & 1 & 1 & 1 & 1 & 0 & 1 & 10 & $77 \%$ \\
\hline 4 & Kulon Progo Regency & 1 & 1 & 1 & 1 & 1 & 1 & 1 & 1 & 1 & 1 & 1 & 1 & 1 & 13 & $100 \%$ \\
\hline 5 & Sleman Regency & 0 & 1 & 1 & 1 & 1 & 1 & 1 & 1 & 1 & 1 & 1 & 1 & 1 & 12 & $92 \%$ \\
\hline \multirow[t]{3}{*}{6} & Yogyakarta City & 1 & 1 & 1 & 0 & 1 & 1 & 1 & 1 & 1 & 1 & 1 & 1 & 1 & 12 & $92 \%$ \\
\hline & Total & 5 & 6 & 4 & 4 & 5 & 5 & 5 & 6 & 6 & 6 & 6 & 5 & 6 & 13 & \\
\hline & Percentage & $83 \%$ & $100 \%$ & $67 \%$ & $67 \%$ & $83 \%$ & $83 \%$ & $83 \%$ & $100 \%$ & $100 \%$ & $100 \%$ & $100 \%$ & $83 \%$ & $100 \%$ & & $88 \%$ \\
\hline
\end{tabular}

Source: Processed data 
Based on the articulation rate analysis results, a deeper analysis was carried out on the local governments in the Special Region of Yogyakarta Province. 6 local governments analyzed in the DIY province had an average LKPD articulation rate of 88 percent. A total of 6 local governments were analyzed; 2 received an articulation level of 100 percent, while the rest had an articulation level of less than 100 percent. The local governments that received a 100 percent articulation level were the Bantul Regency Government and the Kulon Progo Regency Government. It is presented in Table 4.3.

The lowest rate of articulation had a percentage of 69 percent. It was found in the DIY Provincial Government. Among the 13 defined criteria, nine criteria for articulation were met. The unfulfilled articulation criteria were the articulation criteria between LRA and LAK components. Fulfillment of the articulation criteria between components was 100 percent fulfilled in the criteria between LO and LPE, LPE and Balance components, and LAK and LPSAL components. The lowest fulfillment was in the LRA and LAK components criteria, with an average articulation compliance level of 81 percent. The fulfillment rate of the Balance and LAK articulation of 83 percent. Because the DIY Provincial Government had the lowest articulation rate for the DIY Province, it was determined as the regional government to be interviewed in primary data collection. The results of the Yogyakarta Provincial Government's articulation scores can be seen in Table 4.4 .

\subsection{Analysis of LKPD Articulation Effect on Financial Statement Quality}

Based on the previous document data analysis, the researcher determined that the Provincial Government of the Special Region of Yogyakarta was the party being interviewed since it had the lowest articulation rate for the DIY province by 69 percent. The regional apparatus to be interviewed was the Financial and Asset Management Agency (BPKA). The section of BPKA interviewed was primarily the section for the Revenue Budget, Expenditure Budget Division, and Accounting Division. 
Table 4.4

Calculation of Articulation of LKPD in 2018 Special Regional Government of Yogyakarta

\begin{tabular}{|c|c|c|c|c|c|c|}
\hline Articulation & Criteria & \multicolumn{2}{|c|}{ Compared Number (Rp) } & Difference (Rp) & Score & Code \\
\hline \multirow{2}{*}{ LRA \& LPSAL } & $\begin{array}{c}\text { SiLPAValue in LRA = Current Year } \\
\text { SiLPA Value in LPSAL }\end{array}$ & $471,794,246,868.94$ & $471,794,246,868.94$ & & 1 & A. 1 \\
\hline & $\begin{array}{c}\text { Previous end-year SiLPA in LRA = } \\
\text { Initial SiLPA in LPSAL }\end{array}$ & $344,066,436,138.18$ & $344,066,436,138.18$ & & 1 & A. 2 \\
\hline \multirow{4}{*}{ LRA \& LAK } & $\begin{array}{c}\text { Income in LRA = Cash Inflows from } \\
\text { Operating Activities + Cash Inflows } \\
\text { from Investing Activities - Proceeds } \\
\text { from Sales of Segregated Regional } \\
\text { Assets - Disbursement of Reserve } \\
\text { Funds }\end{array}$ & $5,443,179,144,512.93$ & $5,446,131,341,444.93$ & $-2,952,196,932.00$ & 0 & B. 1 \\
\hline & \begin{tabular}{|c|} 
Funding Receipts - Use of SILPA - \\
Disbursement of Reserve Funds - \\
Proceeds from Sales of Separated \\
Regional Assets = Cash Inflows from \\
Funding Activities \\
\end{tabular} & $2,952,196,932.00$ & & $2,952,196,932.00$ & 0 & B. 2 \\
\hline & \begin{tabular}{|c|} 
Expenditure and Transfer $=$ Cash \\
Outflows from Operating Activities + \\
Cash Outflows from Investing \\
Activities - Formation of Reserve Funds \\
- Government Equity Participation \\
\end{tabular} & $5,296,403,530,714.17$ & $5,298,403,530,714.17$ & $-2,000,000,000.00$ & 0 & B. 3 \\
\hline & \begin{tabular}{|c|} 
Financing Expenditures - Establishment \\
of Reserve Funds - Government Equity \\
Participation - Regional Loans = Cash \\
Outflows from Funding Activities \\
\end{tabular} & $2,000,000,000.00$ & & $2,000,000,000.00$ & 0 & B. 4 \\
\hline Articulation & Criteria & \multicolumn{2}{|c|}{ Compared Number (Rp) } & Difference (Rp) & Score & Code \\
\hline
\end{tabular}




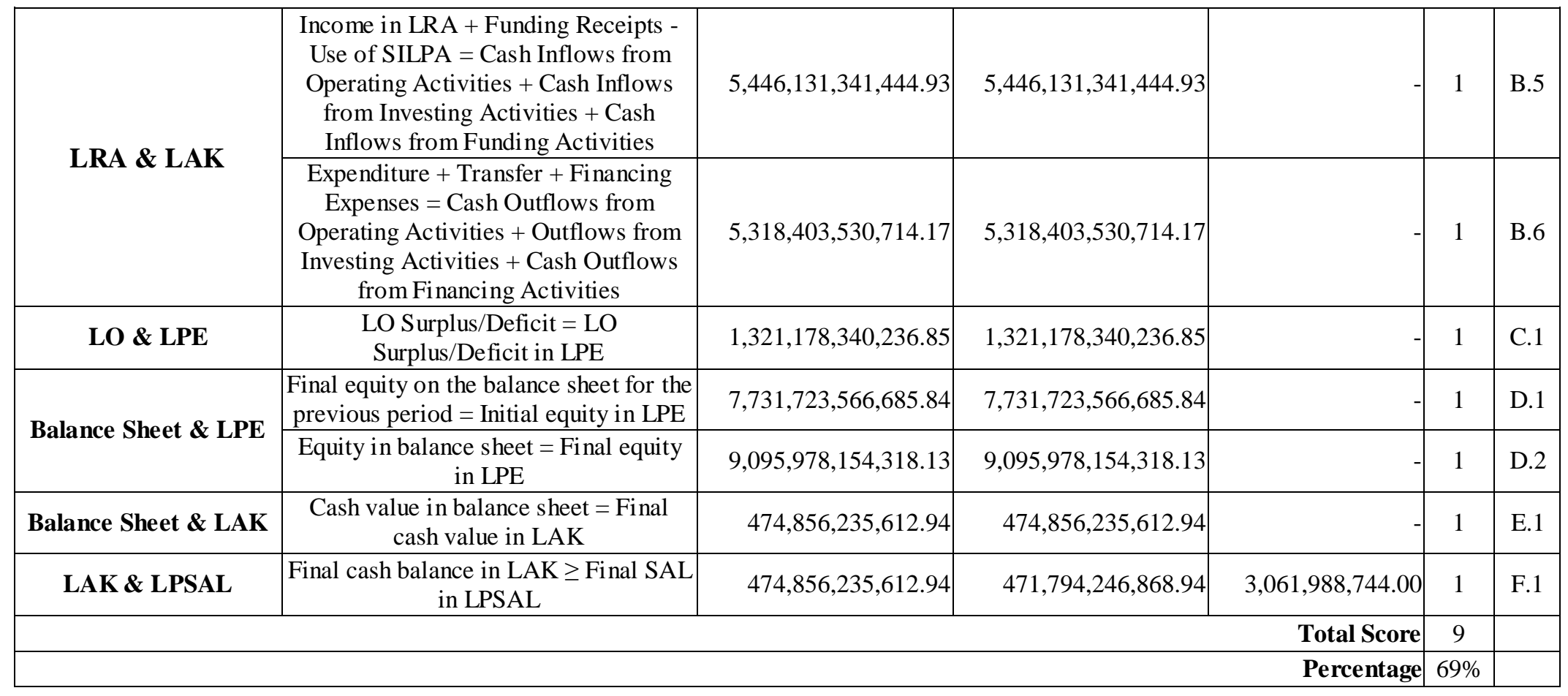


The analysis of the interview data stated that the articulations must be contained in the financial statements. However, document data analysis shows that 70 percent of LKPD had less than 100 percent articulation rate. The inarticulation occurred because of differences in the numbers compared to the articulation criteria. Inarticulation can have fatal consequences on the reliability of a financial statement. Reliability is one of the qualitative characteristics of financial statements, which is the criteria for quality financial statements. However, the inarticulation or mismatch between the LKPD components did not affect the financial statements' quality as long as they are disclosed and explained in the Notes to the Financial Statements (Government Regulation No. 71/2010; Mahmudi, 2016; Firdaus \& Ritonga, 2018). Moreover, if the prepared financial statements do not violate BPK-RI regulations, the quality of the financial statements can still be trusted (Standard Pemeriksaan Keuangan Negara, 2017).

In maintaining the quality of financial statements, the Inspectorate or Internal Supervisory Apparatus (API) as the internal auditor reviews financial statements before submitting them to the BPK. The purpose of this financial statement review is to provide limited assurance on the financial statements submitted. This review is conducted to ensure that the financial statements presented are free from material misstatement. Both the BPK and the Inspectorate see articulation in reviewing financial statements.

This lack of articulation in local governments occurs due to different classifications in the format of financial statements. There are local governments that still use the cash to accrual-based financial statement format. It is related to a change in the basis from cash basis to accrual basis since 2015. This difference is because each local government uses different financial statement application systems. The decision to use the recording application system depends on the decision of each regional head. To overcome these differences that affect the articulation and quality of the LKPD information produced, the central government plans to use the application system. The same recording application system for all local governments is expected to be realized in 2021. 


\subsubsection{Analysis of Financial Statement Effect on Economy Decision-Making}

LKPD is one of the considerations in making economic decisions. One of the economic decisions is decisions in budget preparation. LKPD is used as comparative data in the preparation of the following year's budget. Also, LKPD is used to analyze the rationality of the proposed APBD. According to the sources, the financial statement most often used in making economic decisions is the Budget Realization Report (LRA). The use of LRA compared to other financial statement components is because LRA is easier to use. Besides, APBD that uses a cash basis considers LRA easier to compare and consider when formulating the APBD.

LKPD articulation that affects the quality of financial statements will also affect economic decisions. This linkage results from the use of LKPD in making economic decisions, especially in the APBD preparation process. The poor quality of LKPD can lead to not being optimal in making economic decisions (Christiana, 2017; Firdaus \& Ritonga, 2018). The non-optimization can be in the form of irregularities or habits in the preparation of the APBD.

The influence of the articulation and quality of these financial statements will be considered in preparing the pure APBD and changes to the APBD. The influence of articulation and the quality of the 2018 financial statements affects the changes in the 2019 APBD and the preparation of the 2020 pure APBD. In other words, the articulation and quality of the Year $\mathrm{N}$ financial statements affect the process of changing the APBD in $\mathrm{N}+1$ and preparing the pure APBD in $\mathrm{N}+2$. This effect on the quality of financial statement information occurs when under normal conditions. This condition occurs when the economy is stable, so LKPD data as historical data can predict the future. However, in extraordinary conditions such as the Covid-19 pandemic in 2020, other information besides LKPD is preferred in economic decisions.

\section{Conclusion, Implication, and Limitation}

The results of the analysis of 443 LKPD document data for 2018 with unqualified opinions found that 131 local governments or 30 percent of local governments had a 100 percent articulation rate. Meanwhile, 70 percent or 312 local governments have a 
rate of less than 100 percent. On average, local governments in Indonesia have an average articulation rate of $83 \%$. Specifically, the highest articulation rate per province is Lampung Province, with an average articulation per local government rate of 95 percent. In comparison, the lowest articulation rate was in the DKI Jakarta Province area, with an articulation rate of 54 percent. Of the 13 defined articulation criteria, the most fulfilled criteria were the criteria between LO and LPE components with a 99 percent compliance rate. The least fulfilled articulation criteria were the articulation criteria between LRA and LAK components. The articulation fulfillment of these components was $74 \%$. The articulation criteria rarely fulfilled were the articulation criteria for SAR and LPSAL, with a compliance rate of 77 percent.

Financial statements' articulation must be contained in financial statements because financial statements are fundamentally related to one another (fundamentally related financial statements). If there is an articulation, it will affect the quality of the financial statements (Government Regulation No. 71/2010). However, if the inarticulation can be explained in the Notes to Financial Statements, the financial statements' quality can still be trusted and used in making economic decisions. The findings of this research are in line with the result of Christiana's research (2017) and Firdaus \& Ritonga (2018). The economic decisions referred to are decisions made in the budget preparation process. The previous year's LKPD was used as a comparison and prediction tool in the budget preparation process.

The suggestion from this study is that it is expected that future researchers can use LKPD documents for more than one year so that they are more comprehensive and can observe annual developments. The central government should establish the same recording application system between local governments to increase the comparability of the preparation of financial statements. Local governments should be more cautious in drafting LKPD and also optimize LKPD reviews by the inspectorate general. For the BPK-RI, it is better to look more carefully at the articulation and the format of local government financial statements. Given that local governments still use the financial statement format from a cash basis to an accrual basis. 


\section{Reference}

Bahnson, P. R., Miller, P. B. ., \& Budge, B. P. (1996). Non Articulation in Cash Flow Statements and Implications for Education, Research and Practice. Accounting Horizons: A Quarterly Publication of the American Accounting Association, 10(4), 1-15.

BPK RI. (2019). IHPS I Tahun 2019. Ikhtisar Hasil Pemeriksaan Semester I Tahun 2019, 1426.

BPK RI. (2017). Standar Pemeriksaan Keuangan Negara.

Chen, H., Tang, Q., Jiang, Y., \& Lin, Z. (2010). The role of international financial reporting standards in accounting quality: Evidence from the European Union. Journal of International Financial Management and Accounting, 21(3), 220-278. https://doi.org/10.1111/j.1467-646X.2010.01041.x

Christiana, H. (2017). Eksplorasi Artikulasi Laporan Keuangan Pemerintah Daerah Se Jawa Dan Bali. Universitas Gadjah Mada.

Creswell, J. W. (2014). Research Design: Qualitative, Quantitative and Mixed Methods (4th Editio). Thousand Oaks, CA: Sage Publishing.

Firdaus, M. A., \& Ritonga, I. T. (2018). Analisis Artikulasi Laporan Keuangan Pemerintah Daerah. Jurnal Akuntansi Dan Akuntabilitas Publik, 1(1), 68. https://doi.org/10.22146/jaap.35336

Frischmann, P., Lin, K. C., \& Wang, D. (2019). Analyst Reaction to Non-Articulation between the Balance Sheet and the Statement of Cash Flows. Journal of Applied Accounting Research, 21(1), 163-184. https://doi.org/10.1108/JAAR-02-2019-0036

Frischmann, P., Plewa, F., \& Santhanakrishnan, M. (2010). A Longitudinal Perspective of NonArticulation in the Statement of Cash Flows. Academy of Accounting and Financial Studies Journal, 14(3), 43.

Halim, A., \& Bawono, I. R. (2011). Pengelolaan Keuangan Negara-Daerah (Hukum, Kerugian Negara, dan Badan Pemeriksa Keuangan). (Edisi Pert). Yogyakarta: UPP STIM YKPN.

Jones, W., \& Irvine, T. (2004). Introduction to Management Accounting: a user perspective.

Kieso, D. E., Weygandt, J. J., \& Warfield, T. D. (2018). Intermediate Accounting (J. W. \& S. Inc. (ed.); 3rd ed.).

Kinnunen, J., \& Koskela, M. (1999). Do Cash Flows Reported By Firms Articulate With Their Income Statements And Balance Sheets? Descriptive Evidence From Finland. European Accounting Review, 8(4), 631-654. https://doi.org/10.1080/096381899335745

Krippendorff, K. (1981). Content Analysis: An Introduction to Its Methodology. Sage 
The Indonesian Journal of Accounting Research - Sept, Vol. 24, No.3, 2021

Publication.

Mahmudi. (2016). Analisis Laporan Keuangan Pemerintah Daerah (2nd ed.). Yogyakarta: UPP STIM YKPN.

Miles, M. B., \& Huberman, A. M. (2014). Analisis Data Kualitatif (Terjemahan) (Universitas Indonesia (UI-Press) (ed.)).

Moleong, L. J. (2015). Metodologi Penelitian Kualitatif (P. R. Rosdakarya (ed.); 34th ed.).

Nkundabanyanga, S. K., Tauringana, V., Balunywa, W., \& Emitu, S. N. (2013). The Association between Accounting Standards, Legal Framework and the Quality of Financial Reporting by a Government Ministry in Uganda. Journal of Accounting in Emerging Economies, 3(1), 65-81. https://doi.org/https://doi.org/10.1108/20440831311287709

Nurfaidah. (2013). Hubungan Kualitas Informasi Akuntansi Keuangan Syariah Dengan Kinerja Keuangan Baitulmal Wattamwil (BMT) Di Kota Makassar. AKMEN Jurnal Ilmiah, 104(1042013).

Peraturan Pemerintah Republik Indonesia Nomor 71 Tahun 2010 Tentang Standar Akuntansi Pemerintahan, (2010).

Ritonga, I. T. (2010). Reviu laporan keuangan pemerintah daerah. In Lembaga Kajian Manajemen Pemerintah Daerah. LKMPD.

Ritonga, I. T. (2017). Akuntansi Keuangan Pemerintah Daerah Pengantar. Yogyakarta: Pustaka Pelajar.

Salim, A., Bakker, E., Balasubramanian, T. V, Bharadya, K., Chaudhry, A., Coetsee, D., \& Dougherty, J. (2019). Wiley Interpretation and Application of IFRS Standards. In Wiley Interpretation and Application of IFRS Standards. https://doi.org/10.1002/9781119579748

Sekaran, U., \& Bougie, R. (2016). Research Methods For Business: A Skill Building Approach (7th Editio). United Kingdom: John Wiley \& Sons, Inc.

Sugiyono. (2015). Memahami penelitian kualitatif. In Bandung: Alfabeta. Alfabeta.

Suwardjono. (2013). Teori akuntansi: Perekayasaan Pelaporan Keuangan (Edisi 3). Yogyakarta: BPFE.

Undang-Undang Republik Indonesia Nomor 17 Tahun 2003 Tentang Keuangan Negara, (2003).

Undang-Undang Republik Indonesia Nomor 23 Tahun 2014 Tentang Pemerintah Daerah, (2014).

Widarsono, A. (2007). Pengaruh Kualitas Informasi Manajemen Terhadap Kinerja Manajerial. Jurnal Akuntansi FE Unsil, Vol. 2, No. 2, 2007 ISSN : 1907 - 9958, 2(2), 286-299. 
Wolk, H. I., Dodd, J. L., \& Rozycki, J. J. (2013). Accounting Theory (8th edition). Los Angeles, California: Sage Publications. 
The Indonesian Journal of Accounting Research - Sept, Vol. 24, No.3, 2021

\section{intentionally blank}

